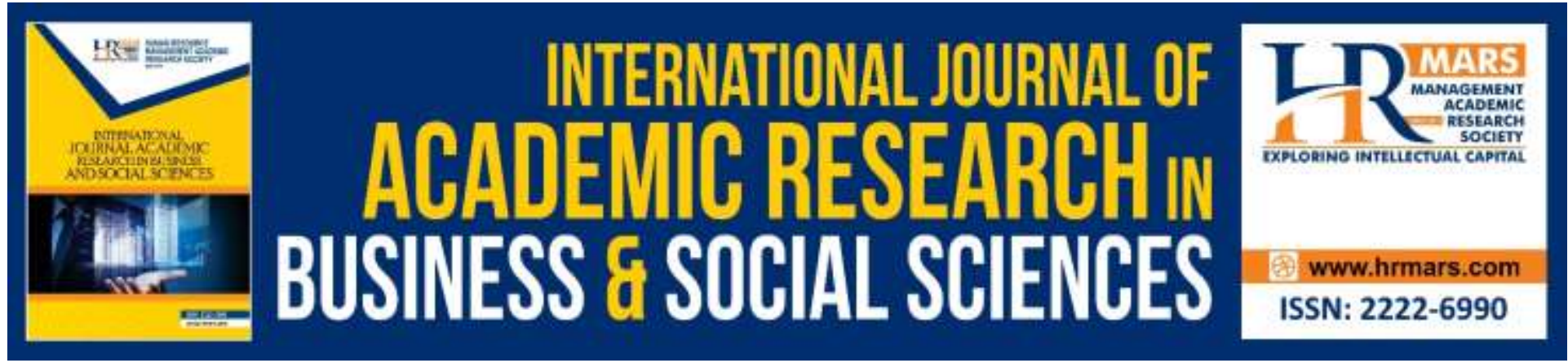

\title{
The Needs Analysis of Developing Mobile Learning Application for Cybergogical Teaching and Learning of Arabic Language Proficiency
}

\begin{abstract}
Wan Ab Aziz Wan Daud, Wong Kung Teck, Mohammad Taufiq Abdul Ghani, Saipolbarin Ramli
\end{abstract}

To Link this Article: http://dx.doi.org/10.6007/IJARBSS/v9-i8/6206

DOI: $10.6007 /$ IJARBSS/v9-i8/6206

Received: 24 June 2019, Revised: 12 July 2019, Accepted: 29 July 2019

Published Online: 13 August 2019

In-Text Citation: (Daud, Teck, Ghani, \& Ramli, 2019)

To Cite this Article: Daud, W. A. A. W., Teck, W. K., Ghani, M. T. A., \& Ramli, S. (2019). The Needs Analysis of Developing Mobile Learning Application for Cybergogical Teaching and Learning of Arabic Language Proficiency. International Journal of Academic Research in Business and Social Sciences, 9(8), 33-46.

Copyright: (C) 2019 The Author(s)

Published by Human Resource Management Academic Research Society (www.hrmars.com)

This article is published under the Creative Commons Attribution (CC BY 4.0) license. Anyone may reproduce, distribute, translate and create derivative works of this article (for both commercial and non-commercial purposes), subject to full attribution to the original publication and authors. The full terms of this license may be seen at: http://creativecommons.org/licences/by/4.0/legalcode

Vol. 9, No. 8, 2019, Pg. 33 - 46

Full Terms \& Conditions of access and use can be found at http://hrmars.com/index.php/pages/detail/publication-ethics 


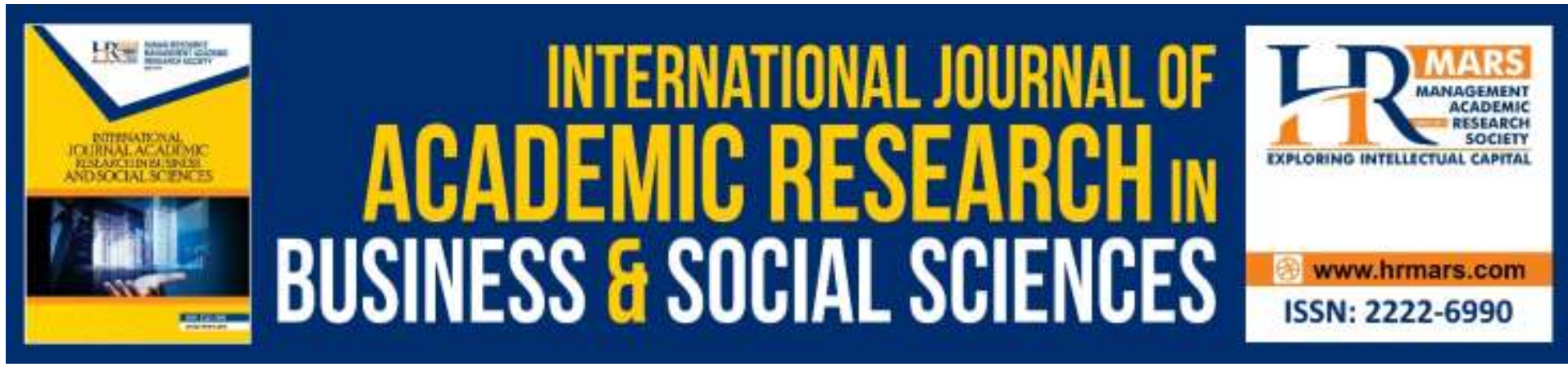

\title{
The Needs Analysis of Developing Mobile Learning Application for Cybergogical Teaching and Learning of Arabic Language Proficiency
}

\author{
Wan Ab Aziz Wan Daud \\ Department of Third Language, Centre for Languages and Generic Development, Universiti \\ Malaysia Kelantan, Malaysia \\ Wong Kung Teck \\ Department of Educational Studies, Faculty of Human Development, Universiti Pendidikan \\ Sultan Idris, Malaysia \\ Mohammad Taufiq Abdul Ghani, Saipolbarin Ramli \\ Department of Modern Languages, Faculty of Languages and Communication, Universiti \\ Pendidikan Sultan Idris, Malaysia
}

\begin{abstract}
The advancement of technology has undoubtedly brought rapid changes and contributed to the rise to developments in many aspects of life, including in education. Consequently, the roles of educators and practitioners have undergone significant changes as teaching and learning tools, as well as educational materials become more diversified and learning takes place in a borderless world of shared resources. Exciting transformations in education that should be embraced and further explored, especially in language teaching and learning because language is an essential part of communication. Language has also become an important requirement for employment and a key success factor in life. This paper aims to explore the potential use of "Cybergogy" in T\&L by emphasising the use of cybergogical tools in learning. To ensure the effective use of these tools, we have employed an appropriate instructional design. Sets of questionnaires on students' needs and perceptions were administrated to 196 Malaysian's university students studying the elementary Arabic language course. Descriptive quantitative analysis, through the use of IBM SPSS statistical software, was employed to analyse the data collected. The results show that there are positive responses over the adoption of technological tools for language learning as it increases students' motivation to learn Arabic.
\end{abstract}

Keywords: Cybergogy, Language Learning, Arabic, Needs Analysis, Mobile Application 


\section{Introduction}

The world has seen a rapid emergence of technology-supported devices, particularly those utilising the wireless communication technology. As technology grows, humans are increasingly dependent on mobile devices in all areas of our lives. Such occurrence has sparked the increase of higher capabilities mobile devices. The emergence of mobile devices has brought massive impacts on the field of education, especially in language learning and mobile learning. This is shown by the extensive use of mobile gadgets, such as Tablet PC, smartphones and iPads, in the learning environment. From here it is evident that devices like smartphones have great potential in the invisible integration of technological hardware into language learning, hence, it is important to ensure that educational practices can include these technologies in productive ways (Abu Sa'alek, 2014). The traditional teaching practices used by the lecturers caused the main of demotivating factors for student in learning and mastering Arabic language (Aladdin, 2013). As a digital generation living in a modern age, modern technology is an integral part of our lives and many students rely heavily on technology to facilitate their daily work and affairs (MyMetro, 2015). The use modern technology as educational materials could increase students' and motivation to learn Arabic language and instill the concept of their own learning environment. (Shahrizal, et al., 2016). This situation undoubtedly highlights the urgent need for the current educational and learning landscape to follow, track and to keep updated with the rapid developments of modern technology.

In the meantime, the effectiveness of mobile application for learning language has been proven effective and efficient (Grimus \& Ebner, 2015). The use of a mobile application has the prospect of creating a transformation in the education process. It is anticipated to remodel education era that demands fresh and exciting concepts. As a result, mobile applications are widely used as a learning medium. The e-learning concept is often linked to the provision of systematic and quality system and increasing the growth of content or course materials, however, the adoption of these concepts in the context of Arabic language education is still limited and has yet to reach a wide number of students. In this regard, while providing the Learning Management System as a platform for delivering learning and teaching materials is not a major issue, researchers have identified the deficiency in Arabic language teaching materials that meet the systematic and quality system provision or other commonly used elearning concepts as the key hindrance in employing e-learning concepts in Arabic language education.

The usability of the app and how it contributes to the growth of the course are crucial for the development of Arabic language in the era of information and communication technology. (Ghalib, 2006) in his study of technology and Arabic language has formulated that the use of technology should be made as ambitious as possible to meet the current needs so that the Arabic language could progress along with the rapid development of information and communication technology. It is also important to systematize the adoption of technology with pertinent knowledge and readiness as teachers should be skilled to utilize technologybased teaching materials. In this light, there are still no pilot studies which have ascertained the role of mobile applications in the development of Arabic language teaching particularly in Malaysia (Janudin \& Arsyad, 2004).

It is argued that mobile devices, especially smartphones, can provide an attractive and effective learning platform which promote active learning and provide a convenient learning platform. The intersecting areas of mobile learning and language learning have been 
combined into an enhanced way of e-learning called m-learning (Rias, 2012); m-learning involves the use of a mobile application, which is a computer program designed to run on mobile devices. Mobile applications, or apps, can be categorised into three-native apps, web apps and hybrid apps (Budiu, 2013). Past works have advocated that the use of mobile applications and tools as it can promote learning flexibility and portability (Fahad, 2009). Mobile apps enable learners to access the learning applications at different places to defy the constraints of time and space. Consequently, learning can happen beyond the classroom walls.

In the meantime, researchers are concerned with how mobile technologies and devices can be efficiently used to support teaching and learning (Kukulska-Hulme, A. \& Shield, L., 2008) and to ensure effective use of mobiles devices in an educational setting. There is a need to differentiate between educational and entertainment mobile application and that pedagogical elements should be integrated into mobile apps to ensure that the learning outcomes could be achieved, and at the same time, students enjoy learning in their class. Based on this argument, several elements should be considered and included in order to develop a useful mobile application for learning purposes (Ogata, 2010). Past works have highlighted the five features of MALL, which are, accessibility, interactivity, immediacy, permanency and situating of instructional activities. Thus, this paper has considered the aforementioned main factors to present a need analysis in developing a mobile application for Arabic language learning based on students' needs and their necessities to fill in the gap in the current pedagogical practice.

\section{Integrating Cybergogical Elements in Mobile Application Development}

The use of mobile applications for Arabic language learning in Malaysia is still in the infancy stage and more improvements are needed. In recent years, many researchers and educators have included the use of mobile devices as an initiative to facilitate learning to ensure students are enjoying language learning, to help retain their motivation to learn and to improve their proficiency. Despite the massive interest, there is still many more elements that need to be explored in this area, particularly in the development of mobile applications. There is no standard procedure in combining the two components, and there is no agreement on the issue of merging these components (Hamizul \& Rahimi, 2015; Ghani, et al., 2018). In this regard, there are several related mobile applications that have been designed to facilitate Arabic language learning in Malaysia. These include mobile app for trilingual Islamic banking and finance (IBF) glossary (Dollah, 2017) and i-Mutawwif (Sahrir, 2018).

Here, the researchers have integrated the pedagogical elements of the Cybergogy model of engaged learning (figure 1) to the systemic development of mobile applications for online learning (Wang, 2008), and to differentiate between educational mobile applications and entertainment mobile applications. 


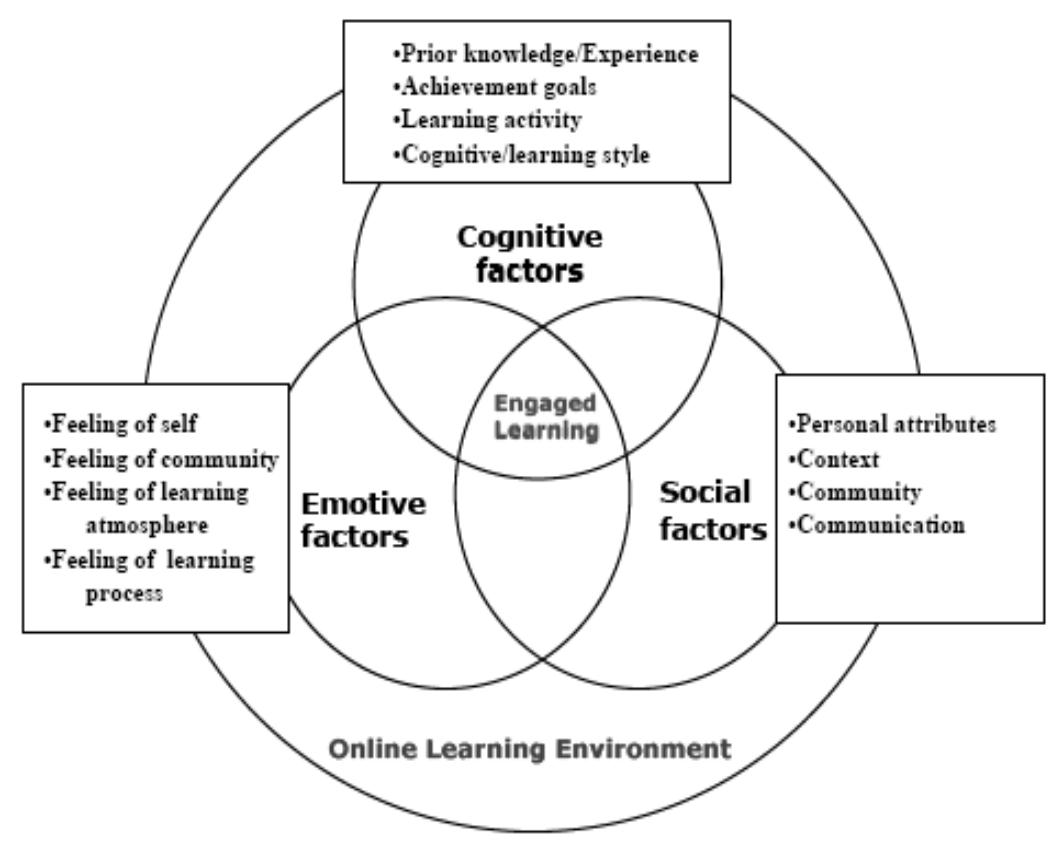

Figure 1: Cybergogy model of engaged learning (Wang, 2008)

The researchers have also considered several major elements and pedagogical issues, such as learning objectives, outcomes, contents, teaching methods and approaches. Moreover, KEMGERLY instructional design framework in designing and developing mobile application for learning Arabic language proficiency (Wan Daud, et al., 2018), as illustrated in Figure 2 was adopted in order to produce an effective mobile application for learning purpose, :

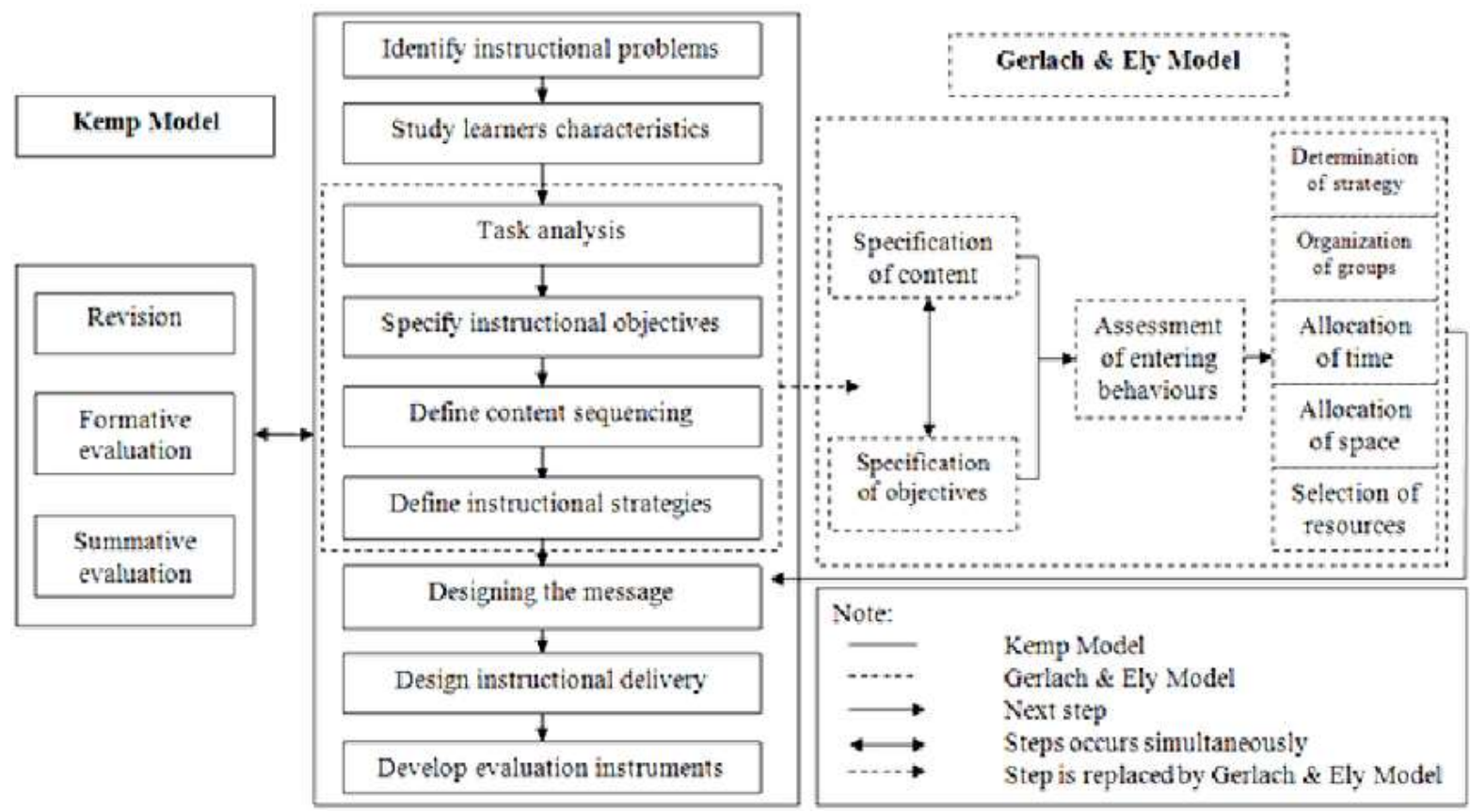

Figure 2: Integration Framework of Pedagogical Elements 
The development of this mobile application for language learning involved several stages. In this study, both the Kemp's Model and Gerlach \& Ely Model are integrated to construct an Arabic language application (Hadi, 2010). This non-linear cycle has no starting and ending point and may start at any related elements. These models are almost similar as both are classroom-oriented and have their own advantages and disadvantages. In this regard, the Kemp model provides a basic framework for the module construction process. Hence, the Gerlach \& Ely model is integrated to replace some elements in the Kemp Model as the steps are more detailed. Consequently, these models are modified and combined to form the KemGerly Model to fit the context of this study.

The researcher has systematically followed the step by step guidelines in every phase to develop a prototype of the application. The instructional design process generally starts with a series of analyses, needs analysis, task analysis, and instruction analysis. Therefore, the Kemp Model will be adopted in the analysis phase to identify issues faced in the instruction and setting the objective to design an instructional program. Next, the researcher will examine students' characteristics and background before identifying the tasks, setting learning objectives, planning the learning content, and designing the learning strategy.

As most learning outcomes are focused on the students' learning experiences, we believe that there is also a need to examine whether students' achievements have improved after using mobile application for language learning. At the same time, student's motivation and their perceived of acceptance should also be included into the outcomes of using mobile application in the teaching and learning process.

\section{Methodology}

The KemGerly design framework was applied to develop the mobile application. In this regard, the development of mobile applications normally comprises of five stages - Analysis, Design, Development, Implement and Evaluation (Malachowski, 2002). In this light, each stage has been iterated based on the feedback, suggestions and opinions provided by users, developers and subject matter experts. However, this paper only reports the first stage of the KemGerly design framework, which refers to the need analysis conducted to probe on the learners' characteristics, needs and preferences.

The research participants were purposively selected from Malaysian university students studying Arabic for foreign language in five (5) selected universities. In this study, the students are grouped based on their needs and preferences which have been determined through a set of needs analysis questionnaire adapted from Ghalib, et al. (2016), Ghani, et al. (2016), Sahrir, et al. (2017). The sets of questionnaires were distributed to 196 students and contain three parts- Part A which probes on the learners' demographic background, part B elicits the learners' need and part $C$ probes on the hindrance the learners faced in learning the Arabic language. This study employed descriptive quantitative analysis and the IBM SPSS statistical software was used to analyze the data. In this regard, the respondents' demographic information are presented in percentage and tables of frequencies. Meanwhile for part $B$ and $\mathrm{C}$, the 5-point Likert Scale, anchored by strongly disagree, disagree, not sure, agree and strongly agree, was used to determine the level of learners' agreement on the statements. The mean scores for each item in part $B$ and $C$ were used to determine the score. 


\section{Results and Finding}

The results and findings are presented below:

\section{A) Demographic Background}

The findings revealed the learners' need, necessities and lack in learning Arabic language communication using mobile application. As mentioned, the data for this study were obtained from the questionnaire and calculated using the descriptive statistics function in SPSS version 22. This study's findings were then presented in three sections, learners' demographic information, learners' needs and their necessities and learners' obstacles in learning the Arabic language. The results are shown below:

\begin{tabular}{|c|c|c|c|}
\hline Items & Sub-items & $(\mathrm{N})$ & (\%) \\
\hline \multirow{3}{*}{ Age } & $19-21$ & 7 & 3.6 \\
\hline & $21-23$ & 184 & 93.9 \\
\hline & $23-25$ & 5 & 2.6 \\
\hline \multirow{2}{*}{ Gender } & Male & 93 & 47.4 \\
\hline & Female & 103 & 52.5 \\
\hline \multirow{15}{*}{ Institutions } & $\mathbf{A}$ & 41 & \multirow[t]{3}{*}{20.9} \\
\hline & Male & 15 & \\
\hline & Female & 26 & \\
\hline & B & 40 & \multirow[t]{3}{*}{20.4} \\
\hline & Male & 12 & \\
\hline & Female & 18 & \\
\hline & C & 20 & \multirow[t]{3}{*}{10.2} \\
\hline & Male & 6 & \\
\hline & Female & 14 & \\
\hline & D & 80 & \multirow[t]{3}{*}{40.8} \\
\hline & Male & 33 & \\
\hline & Female & 47 & \\
\hline & $E$ & 15 & \multirow[t]{3}{*}{7.7} \\
\hline & Male & 5 & \\
\hline & Female & 10 & \\
\hline Items & Sub-items & (N) & (\%) \\
\hline \multirow{3}{*}{ Age } & $19-21$ & 7 & 3.6 \\
\hline & $21-23$ & 184 & 93.9 \\
\hline & $23-25$ & 5 & 2.6 \\
\hline \multirow{2}{*}{ Gender } & Male & 30 & 15.3 \\
\hline & Female & 166 & 84.7 \\
\hline
\end{tabular}

Table 1: Demographic Background

Table 1 presents the demographic backgrounds of the Arabic language learners. The respondents were students from higher education institution in Malaysia who are enrolled in the Arabic language class for the 2017/2018 academic year. Most of the respondents are aged between 21 to 23 with (94\%). Meanwhile, $70 \%$ of the respondents said that they use android smartphones while $82.7 \%$ of the respondents use Wi-Fi to access the internet. 
B) Ownership Purposes of Mobile Devices

\begin{tabular}{llcc}
\hline Items & Sub-items & (N) & (\%) \\
\hline \multirow{4}{*}{ Device Ownership } & Android & 136 & 69.4 \\
& Apple IOS & 51 & 26.0 \\
& Windows Phone & 5 & 2.6 \\
& Blackberry & 1 & 0.5 \\
& Others & 3 & 1.5 \\
\hline \multirow{5}{*}{ Internet Accessibility } & Wi-Fi & 162 & 82.7 \\
& Broadband & 17 & 8.7 \\
& Hotspot & 4 & 2.0 \\
& Others & 13 & 6.6 \\
\hline \multirow{5}{*}{ Reason for having devices } & Communication & 132 & 67.3 \\
& Education & 47 & 24 \\
& Entertainment & 5 & 2.6 \\
& Business & 4 & 2.0 \\
& Others & 8 & 4.1 \\
\hline
\end{tabular}

Table 2: Ownership Purposes of Mobile Devices

As shown in Table 2, 67.3\% of respondents use their devices for communication and $24 \%$ use their device for education purposes, this is followed by Entertainment (2.6\%), Business (2.0\%) and others (4.1\%). Since the respondents are from higher education level, the findings have shown some insights in their use of mobile devices for academic and communication. In this light, the learners are from the generation $Y$ who have more opportunities to access mobile learning, e-learning and distance learning due to the abundance of affordable smartphones and tech devices in the market. Furthermore, compared to the 5-10 years ago, the devices available in the market normally have higher specifications and this has made it easier for learners to use the devices to fulfil their academic, social and economic needs including communicating, accessing apps, watching videos and conducting online business transactions. 
C) Learner's Need and Necessity

\begin{tabular}{lccc}
\hline \multicolumn{1}{c}{ Items } & (N) & Mean & Score \\
\hline Simple Greeting Words & 196 & 4.37 & Very high \\
Arabic Language Terms & 196 & 4.16 & Very high \\
Basic Conversation & 196 & 4.37 & Very high \\
Basic Arabic Culture & 196 & 3.76 & Very high \\
Basic Sentence & 196 & 4.27 & Very high \\
Listening Comprehension & 196 & 3.90 & Very high \\
Reading & 196 & 4.33 & Very high \\
Speaking & 196 & 4.06 & Very high \\
Writing & 196 & 4.08 & Very high \\
Main Menu Interface & 196 & 2.34 & High \\
Arabic Text script & 196 & 4.37 & Very high \\
Arabic Term Transliteracy & 196 & 4.66 & Very high \\
Audio Pronunciation & 196 & 4.54 & Very high \\
Translation & 196 & 4.55 & Very high \\
Vocabulary & 196 & 4.41 & Very high \\
Video & 196 & 4.51 & Very high \\
\hline
\end{tabular}

Table 3: Learner's Need and Necessity

The students were also asked to choose $t$ their needs and necessities elements used for the delivery of the app, and the preferred interface design. The results are shown in in Table 3. According to them, the most essential language components that they need to learn are simple greeting with the mean score of 4.37, basic conversation (4.37) and basic sentences (4.27). The students also believe that they need to improve the four basic language skills. In this light, as the respondents are learning Arabic as a foreign language, they highly prefer the use of multimedia elements like pictures, hypertexts, text transliteracy and videos in their lessons. 
D) Learners' Obstacles

\begin{tabular}{|c|c|c|c|}
\hline Items & $(\mathrm{N})$ & Mean & Score \\
\hline $\begin{array}{l}\text { I have difficulties in memorising Arabic } \\
\text { Vocabulary }\end{array}$ & 196 & 3.44 & Very high \\
\hline I don't have any Arabic learning strategies & 196 & 3.33 & Very high \\
\hline I have rarely use Arabic terms. & 196 & 3.70 & Very high \\
\hline $\begin{array}{l}\text { I usually list down all the vocabulary before } \\
\text { memorising them. }\end{array}$ & 196 & 3.76 & Very high \\
\hline $\begin{array}{l}\text { I have difficulties in Learning Arabic language } \\
\text { because teaching methods are not interesting }\end{array}$ & 196 & 2.95 & Very high \\
\hline $\begin{array}{l}\text { I have difficulties in Learning Arabic language } \\
\text { because teaching tools are not effective }\end{array}$ & 196 & 3.58 & Very high \\
\hline $\begin{array}{l}\text { I have difficulties in Learning Arabic language } \\
\text { due to the lack of language activities }\end{array}$ & 196 & 3.72 & Very high \\
\hline $\begin{array}{l}\text { I have difficulties to communicate in Arabic } \\
\text { language fluently }\end{array}$ & 196 & 3.90 & High \\
\hline I have difficulties in understanding Arabic texts & 196 & 3.84 & Very high \\
\hline
\end{tabular}

Table 4: Learner's Obstacle

As shown in Table 4, the most common obstacle faced by learners in understanding Arabic texts (3.84). The rest of the obstacles include listing down all the vocabulary before memorizing (3.76), difficulties due to the lack of language activities (3.72), due to the use of ineffective teaching tools (3.58), rarely use Arabic language Terms (3.70) and the teaching methods used are not interesting (2.95). In this regard, since all of the respondents are not majoring in Arabic language, these statements present the possible explanation on why students are facing problem in understanding Arabic language texts.

\section{Discussion of Results and Findings}

The results and findings of this study have several implications, including, first it highlights the issue of bridging technological innovations and user's satisfaction. Previous results and finding have highlighted the need to build a bridge between technological innovations and user's satisfaction is important to ensure the use of the tools could trigger learning entertainment, engagement, and motivation (Ghalib, et al., 2016; Sahrir et al., 2011; Mable et al., 2002; Lee, 2012). In the present study, information on the learners' prefered device type, level of internet accessibility, reason for owning a mobile device have been probed. The learners have also conveyed their prefered contents that should be included in the mobile application fior learning Arabic language. Thus, this study suggests that the design of the language learning mobile apps should take account these finding to enhance its practicality

The findings of the current study can be used in the step by step development of mobile application for learning Arabic language. The elements which received higher ratings from the respondents could be highlighted and considered during the development. In this regard, the app should contain activities for the acquisition four language skills listening, reading, speaking and writing. Among materials and activities that could be include are simple greeting words, basic conversation, audio texts, video, pictures, Arabic/Malay translations of common terms and Arabic transliteration. This study also found that learners demand real-time 
information and prefer to multi-task and get involved in the parallel language learning process. At the same time, they find that the use of graphics makes the app more interesting compared to text only interface. Gen $Y$ learners also prefer the use of random access, such as hypertext and the use of interactive virtual games over "serious" work. Moreover, we suggest that the app could be accessed using lower bandwidth connection. This is because the learners may find it difficult to access the app without wifi outside of the university. We also believe that app should also be compatible with the ios and Android platforms. An app for the Android platform at the beginning as android phones are more popular among the learners'. On top of that, many respondents stated that they prefer an app with the capability of customising the application interface

According to the respondents, there are some course contents that need to be emphasized in learning Arabic for communication, such as simple greeting word, vocabulary, basic conversation and communication skills (Daud \& Pisal, 2014; Gan, 2012). They stated that courses should help strengthen the core language skills as the lack of basic language skills might hinder them from communicating effectively and to interact with other Arabic spakers. The respondents also shared the difficulties they faced in learning Arabic especially for beginners including the difficulties in memorising Arabic vocabulary. Hence, it will be useful to have a list of Arabic vocabulary along with models of accurate pronunciations of common words. This is to encourage learners to pronounce words correctly to prevent miscommunication. Moreover, learning the correct pronunciation could prepare learners to learn both speaking and writing skills.

Foreign language teachers and lecturers often find it difficult to engaged the students to learn Arabic language. Such challenges and problems faced must be dealt with wisely by applying modern teaching pedagogy, including the use of technologies tools. However, most teachers only use conventional teaching techniques such as lectures, translation and explaining without the use of any exciting teaching aids. According to them, their decisions to do is based on time constraints and the excessive amounts administrative tasks they have to perform . Consequently, the use of old-fashioned techniques and low inventory situations are detrimental to students' interest in learning Arabic. After all, the Arabic language is already being labeled a difficult subject. According to Zunita, et al. (2016), teacher should be versatile and able to use the minimum teaching aids effectivelyunder any circumstances. One way to do so is by mobile app. Thus, as a mean to increase student's interest in learning Arabic language, teachers must be creative in presenting their lessons. In this light, learning through app, or cybergogy, is recommended because it is considered as an interactive approach that could gauge students' interest in learning Arabic language. Past studies have shown that integrating cybergogy approach in teaching \& learning process is more useful compared to the old fashion style. In the meantime, learners are also facing a problem in learning Arabic language due to the use of ineffective tools by teachers in the. In this regard, learning should be executed in interesting, relaxing and enjoyable manners. This could be done by employing appropriate tools which contain online games and vocabulary exercises across different language skills such as speaking, writing and reading and listening, to improve the students' achievement and proficiency in Arabic language. 
An app should also integrate interactive multimedia elements. This Arabic language application could include different multimedia elements such as audio clips that elicit the accurate pronunciation of arabic scripts and to model the vocalisation system or diacritics of common Arabic words and phrases. The video of basic conversations should also be integrated into the application and will help learners to practice and familiarise themselves on how to communicate in Arabic language. All of these multimedia elements will help learners increase their motivation towards learning Arabic language. The integration of these multimedia element in learning reflects the adoption practising the cybergogy approach in learning Arabic language. This app will be a useful addition in the practice of language learning where there are limited number of existing product available in the app store or google play. Thus, this new mobile application for learning Arabic language should be easy to use, fun and efficient to be implemented in current time.

\section{Conclusion}

This paper presents the results and finding of need analysis study among students as part of the development of a mobile application for language learning. The respondents have been in terms of their background, needs and learning obstacles. Overall findings show positive feedback among respondents with regard to the need of design and use of this mobile application for learning process. The respondents also have contributing their suggestions and comments in terms of language content and preferable features of this mobile application. From the findings, we suggest that the mobile application can be developed by providing interactive learning contents, exercises, and tests in the form of high-quality multimedia elements with a user-friendly interface that integrate the fun learning element. In this light, with regards to the future direction, it would be interesting to investigate the effectiveness, motivation and perceived acceptance of mobile applications to determine whether it could enhance or disrupt the learning process. The use of mobile application had a particularly significant on Arabic language learning and confirmed that students did not just socialize online, but they also exhausted this kind of application to improve their Arabic knowledge and skills, while incorporating mobile application into their practices, as an instrument of self learning in both their professional and private life. Consequently, we believe that mobile application boosts learning effectiveness, the transfer and share of knowledge, learners' confidence and interest alike.

\section{References}

Ghani, A. M. T., Hamzah, M., Daud, W. A. A., \& Ramli, S. (2018). Learning Arabic Vocabulary Through Digital Mobile Game Application: Model and Concept Proposed. 2nd International Conference on Language Learning \& Teaching. Pekan: Universiti Malaysia Pahang.

Abu Sa'alek, A. O. (2014). A review of emerging technologies: Mobile assisted language learning (MALL). Asian Journal of Education and e-Learning.

Alias, N., \& Sahrir, M. S. (2009). A Design and Development Approach to researching Online Arabic Vocabulary Games Learning in IIUM. The 2nd International Conference on eLearning (ICEL 2009). Shah Alam: UITM Shah Alam.

Budiu, R. (2013). Mobile: Native apps, web apps, and hybrid apps. Retrieved from Retrieved from http://www.nngroup.com/articles/mobile-native-apps/ 
Daud, N. \& Pisal, N. A. (2014). Permasalahan Pertuturan Dalam Bahasa Arab Sebagai Bahasa Kedua. Gema Online Journal of language Studies, 14, 117-133.

Dollah, N. M. (2017). Prototype development of mobile app for trilingual Islamic banking and finance glossary of terms via iOS and android based devices. International Journal of Interactive Mobile Technologies, 145-161.

Fahad, N. (2009). Students' Attitudes and Perceptions towards the Effectiveness of Mobile Learning in King Saud University. The Turkish Online Journal of Educational Technology - TOJET.

Gan, Z. (2012). Understanding L2 Speaking problems: Implications for ESL Curriculum Development in a Teacher Training Institution in Hong Kong. Australian Journal of Teacher Education, 37, 43-59.

Ghalib, M. F. (2006). The design, development and testing on the efficacy of a pedagogical agent on the performance and program rating scores among students learning Arabic. Pulau Pinang: Unpublished Ph.D. dissertation, Universiti Sains Malaysia.

Ghalib, M. F., Mansor, Y., Dollah, N., Hassan, R., Omar, Z. \& Zakaria, A. W. (2016). Providing a Mobile Service for Academics and Professionals: Need Analysisfor the Development of Mobuile App Glossary of Terms in Islamic Banking and Finance. In J. E. Luaran, Envisioning the Future of Online Learning (pp. 359-369). Singapore: Springer Science+Business Media Singapore.

Hamzul, M. \& Rahimi, N. M. (2015). Design and Development of Arabic Online Games: A Conceptual Paper. Procedia Social and Behavioral Sciences, 174, 1428-1433.

Kukulska-Hulme, A. \& Shield, L. (2008). An overview of mobile assisted language learning: From content delivery to supported collaboration and interaction. ReCALL.

Malachowski, M. J. (2002). ADDIE based five-step method towards instructional design. An online article on Instructional Design Models website by School of Education, University of Colorado, USA.

Ogata, H. Y. B. (2010). Computer supported ubiquitous learning environment for vocabulary learning. International Journal of Learning Technology.

Rias, N. B. (2012). M-Jako Iban: A Mobile Application to Introduce Iban Language. International Symposium on Humanities, Science and Engineering (SHUSER 2012). Kuala Lumpur.

Sahrir, M. S. \& Ghani, A. M. T. (2016). The design of computer courseware in teaching Arabic language via website for students with the specialization of tourism at Poly-Tech College of MARA at Kelantan Darul Naim Malaysia. Journal of Linguistics and Literary Studies Vol 7 No 2, 368-793.

Sahrir, M. S. (2018). Development and evaluation of i-Mutawwif: A mobile language traveller guide in Arabic for mutawwif (Umrah tour guide). International Journal of Interactive Mobile Technologies, 54-68.

Sahrir, M. S., Yahaya, M. F., Zubir, M. A. \& Ismail, T. (2017). ANALYZING THE LEARNERS' NEEDS IN MOBILE LANGUAGE APPLICATION IN ARABIC FOR MUTAWWIF (UMRAH TOUR GUIDE). Journal of Global Business and Social Entrepreneurship (GBSE) Vol 3, 58-72.

Daud, W. A. A., Wong, K. T. \& Ghani, A. M. T. (2018). A Conceptual Framework for Mobile Application in Learning Arabic Language Proficiency. The Journal of Social Sciences Research, 66-70.

Wang, M. J. (2008). Cybergogy for engaged learning. Journal of Open and Distance Education in China, 14-22. 
INTERNATIONAL JOURNAL OF ACADEMIC RESEARCH IN BUSINESS AND SOCIAL SCIENCES Vol. 9, No. 8, August, 2019, E-ISSN: 2222-6990 @ 2019 HRMARS

Zunita M. M., Harun, B., Maimun, A. L. \& Kamalia, N. Y. (2016). Teaching and Learning Arabic Vocabulary: From a Teacher's Experiences. Scientific Research Publishing Inc, 483-490. 